Innowacje w Pielęgniarstwie i Naukach o Zdrowiu

$2(1) / 2016$

ISSN: 2451-1846

DOI: http://dx.doi.org/10.21784/IwP.2016.012

Lucyna Graf ${ }^{1}$, Mariola Śleziona ${ }^{1}$

1Studia Doktoranckie, ZakładFilozofii i Bioetyki Katedry Nauk Społecznych i Humanistycznych, Wydział Nauk o Zdrowiu, Śląski Uniwersytet Medyczny w Katowicach

\title{
Problemy opiekuńcze związane z chorobą Huntingtona
}

\section{Care problems related to Huntington Disease}

\begin{abstract}
Streszczenie
Choroba Huntingtona jest przewlekłą neurodegeneracyjną chorobą, którą się dziedziczy autosomalnie dominująco. Objawy choroby dotyczą zaburzeń motorycznych, poznawczych, zachowania i emocji. Omawiana jednostka chorobowa stanowi szczególne wyzwanie dla rodzin i opiekunów, a także lekarzy, psychologów, rehabilitantów i pracowników opieki socjalnej. Niniejsza praca ma na celu przedstawienie możliwości rozwiązywania problemów związanych z chorobą Huntingtona, problemów związanych z opieką nad chorym, działań pomocowych oraz wsparcia dla chorego i jego bliskich. Konieczna jest edukacja na temat choroby Huntingtona oraz poradnictwo dla opiekunów i personelu medycznego w zakresie radzenia sobie z problemami związanymi z chorobą. Konieczne są również zmiany systemowe i polepszenie dostępu do opieki medycznej i socjalnej oraz tworzenie i współpraca zespołów terapeutycznych.
\end{abstract}




\begin{abstract}
Huntington disease is a chronic neurodegenerative disease and autosomal dominant innate. The symptoms of this disease take the form of motor, cognitive, behavioral and emotional disorders. This diseases is particularly challenging to parents and caregivers, as well as doctors, psychologists, physiotherapists and social care employees. The purpose of this study is to present possible solutions to the problems related to Huntington disease, issues related to the care for the patient, assistance and support for patients and their relatives. It is necessary to educate people about Huntington disease and provide advice to caregivers and medical personnel with regard to dealing with its consequences. There is also a need to modify the existing system, improve the access to medical and social care, as well as create therapeutic teams and cooperate with them.
\end{abstract}

Słowa kluczowe: choroba Huntingtona, opieka, problemy pielęgnacyjne

Key words: Huntington disease, care, care problems

\title{
Wstęp
}

Choroba Huntingtona (HD),jej nazwa pochodzi od nazwiska George'a Huntingtona, który w 1872 roku jako pierwszy opisał jej objawy. Wcześniej była zwana pląsawicą Huntingtona. Pląsawica określa mimowolne ruchy o charakterze płynnym, które przypominają taniec. Ruchy pląsawicze mogą mieć różny stopień nasilenia począwszy od tych dyskretnych aż do uniemożliwiających choremu normalne funkcjonowanie. W średniowieczu choroba była nazywana „tańcem Świętego Wita”, ze względu na mimowolne rytmiczne ruchy twarzy oraz kończyn górnych i dolnych. Chorych na pląsawicę traktowano jak opętanych przez diabła tanecznym szałem. Zajmował się nimi kościół Św. Wita w Strasburgu, stąd wyżej wymieniona nazwa. HD znajduje się na liście rzadkich chorób. Jest genetyczną, postępującą neurodegeneracyjną chorobą ośrodkowego układu nerwowego. Badania dowodzą, iż w Europie i Ameryce Północnej w 100000 populacji choruje od 4 do 8 osób. Często też w jednej rodzinie dotkniętych jest kilka osób, na przykład mąż, dzieci, wnukowie. Zwykle choroba 
rozpoczyna się w 35-40 roku życia. Charakteryzuje się triadą objawów: poznawczych, motorycznych i psychopatologicznych. Jednym z pierwszych objawów jest niezgrabność ruchów.

Niestety pomimo wielu badań do tej pory nie znaleziono lekarstwa i skutecznej terapii, która wyleczyłaby lub opóźniła rozwój HD. Zatem jest to choroba postępująca, ma charakter paliatywny i nieuchronnie prowadzi do śmierci. Do zgonu dochodzi po 15-20 latach jej trwania. Należy zaznaczyć, że postać młodzieńcza HD postępuje szybko i tym samym zgon następuje szybciej. Przyczyną zgonu najczęściej jest zachłystowe zapalenie płuc, które następuje na skutek upośledzenia połykania i przedostania się treści żołądkowej do dolnych dróg oddechowych $[1,2,3,4]$.

Celem pracy jest przedstawienie potrzeb oraz problemów pielęgnacyjnych i opiekuńczych związanych z chorobą Huntingtona.

\section{Genetyka Choroby Huntingtona}

Choroba jest dziedziczona w sposób autosomalnie dominująco. Ryzyko dziedziczenia określa się na 50\%, co oznacza, że mężczyzna lub kobieta dotknięci chorobą mogą w 50\% przekazać wadliwy gen na chromosomie 4, wywołującym HD, każdemu dziecku. Ważną informacją jest fakt, iż w przypadku osób, które nie odziedziczyły zmiany genetycznej choroba nie rozwinie się, jak również nie zostanie przekazana potomstwu.

Natomiast, jeśli statut rodziców nie jest znany, wnuki osób dotkniętych chorobą Huntingtona mogą dziedziczyć chorobę w 25\%. Zdarza się, że HD jest diagnozowane u osób, u których w wywiadzie rodzinnym nie było takiej jednostki chorobowej. Do sytuacji takiej, może dojść gdy przodkowie byli nosicielami, lecz nie byli lub byli błędnie zdiagnozowani.

Za pomocą testów genetycznych istnieje możliwość diagnostyki krewnych chorego, dzięki czemu można stwierdzić, czy dana osoba ma mutację HD. Niestety test nie jest w stanie określić, kiedy choroba zacznie się rozwijać. W Polsce testy genetyczne HD wykonuje 
się bezpłatnie, warunkiem jest skierowanie od lekarza specjalisty. Testom mogą poddać się wyłącznie osoby dorosłe. Obecnie istnieje także możliwość diagnostyki prenatalnej w celu sprawdzenia, czy wadliwy gen przekazało się dziecku.

Ważne jest, by dokładnie określić cel wykonania testu ze względu na brak specyficznego leczenia. Wykonanie rutynowych badań w celu wykrycia choroby może budzić poważne dylematy etyczne, dlatego w przypadku osób decydujących się na ich wykonanie należy indywidualnie rozważyć sytuację chorego i jego rodziny, a po uzyskaniu wyniku ustalić z lekarzem dalsze postępowanie. Wielu potencjalnych nosicieli nie decyduje się na wykonanie testów genetycznych obawiając się życia z piętnem przyszłej choroby. Inną grupę stanowią osoby, które mają świadomość braku możliwości powstrzymania rozwoju choroby, chcą wykonać testy genetyczne, a następnie chcą uregulować sobie sprawy rodzinne, zawodowej majątkowe$[2,5,6]$.

\section{Diagnostyka choroby Huntingtona}

W procesie diagnostycznym największą rolę odgrywa wywiad rodzinny. Należy zwrócić uwagę czy w rodzinie występowały typowe objawy, takie jak zaburzenia ruchowe, przewlekłe zaburzenia depresyjne oraz schizofrenopodobne, a także samobójstwa. W celu rozpoznania choroby pomocne będą badania genetyczne. Natomiast $w$ badaniu morfologicznym można stwierdzić nasilenie zmian zwyrodnieniowych mózgu. Tomografia komputerowa, rezonans magnetyczny może wykazać zaniki płatów czołowych i jądra ogoniastego[6,7].

\section{Objawy i rozwój choroby Huntingtona}

Choroba Huntingtona u większości chorych rozpoczyna się u 2/3 pacjentów od objawów neurologicznych, natomiast u pozostałej części pacjentów zaburzenia psychiczne są objawami dominującymi. Przebieg choroby jest indywidualny, jest zmienny i trudny do przewidzenia. Objawy mogą różnić się w zależności od zakresu, ciężkości 
przebiegu, wieku, kiedy wystąpiły pierwsze objawy, a także szybkości postępu choroby.

Lekarze zaobserwowali wolny rozwój HD u osób, u których choroba ma późny początek, u z większą masą ciała, przez co jej spadek jest mało zauważalny oraz u chorych, u których na początku zachorowania nie występuje depresja, a deficyt intelektualny jest mniejszy. Natomiast szybką progresję choroby zaobserwowano u osób z wczesnym początkiem objawów, będących nosicielami, którzy odziedziczyli zmutowany gen od ojca, niezależnie od płci.

Choroba Huntingtona w typowym przebiegu rozwija się niezauważalnie, a pierwsze objawy nie budzą niepokoju u chorego oraz jego bliskich. Do najwcześniejszych objawów zalicza się spadek masy ciała przy prawidłowej diecie, nieznaczne zaburzenia osobowości, zaburzenia psychiczne oraz niewielkie zaburzenia ruchowe [6].

Wyróżnia się 3 fazy choroby:

Faza wczesna

W fazie wczesnej pacjent jest niezależny i samodzielny, przy czym zaczynają się pojawiać szybkie ukierunkowane ruchy - spojrzenia, zaburzenia gałkoruchowe oraz drobne dodatkowe mimowolne ruchy, które występują rzadko. Pojawiają się delikatne zaburzenia koordynacji ruchowej, natomiast wszelkie zaplanowane ruchy pacjent rozpoczyna w sposób powolny. Występuje lekka zmiana osobowości oraz zaburzenia nastroju. Bardzo często chorego dotyka depresja, pacjent jest drażliwy, lękliwy, występuje labilność emocjonalna oraz subtelne zaburzenia poznawcze. Symptomem ostrzegawczym powinien być rozwój otępienia w młodym i średnim wieku oraz brak świadomości chorego występujących objawów choroby.

Faza średnia

W fazie średniej pacjent jest jeszcze niezależny w niektórych czynnościach, lecz wymaga już pomocy osób drugich. Narastają mimowolne ruchy i związane z tym trudności w wykonywaniu czynności planowych. Występują wyraźne zaburzenia zachowania, pacjent 
bywa agresywny, występują epizody psychotyczne, urojenia na przykład dotyczące romansów i zdrad. Pacjent często jest zazdrosny, wmawia innym wrogość wobec jego osoby. W tej fazie choroby mimowolne grymasy twarzy są już częste i wyraźne, występuje wykręcanie całego ciała oraz ruchy pląsawicze. Zauważalne są zaburzenia funkcji poznawczych, a także narastające otępienie. Chory zaczyna mieć problemy z połykaniem.

Faza zaawansowana

W tej fazie pacjent jest całkowicie zależny od opiekuna, występuje nietrzymanie moczu i stolca, narastają zaburzenia motoryczne i poznawcze, pogłębia się otępienie oraz obojętność.

Choroba Huntingtona charakteryzuje się objawami neurologicznymi, do których należą mimowolne, pląsawicze ruchy zarówno ogniskowe, jak i uogólnione. Ruchy te powodują zaburzenia w artykulacji oraz w połykaniu. Pacjent nie może utrzymać wysuniętego języka oraz nie potrafi utrzymać stałego nasilenia ucisku ręki, tak zwany objaw dojarki. Wśród występujących objawów neurologicznych możemy wyróżnić objawy pozapiramidowe, takie jak napadowe zaburzenia ruchowe, czyli mioklonie oraz wokalizacje, które przypominają tiki wokalne. Do innych objawów neurologicznych występujących w chorobie Huntingtona należą sztywność mięśni, spowolnienie ruchowe, dystoniczne ruchy oraz zaburzenia postawy. Obserwuje się także objawy piramidowe, najbardziej charakterystyczne są mimowolne skurcze włókien mięśniowych tak zwany klonus inaczej trząs. Innymi objawami są spastyczność mięśni, objaw Babińskiego, zaburzenia chodu i tym samym zaburzenia równowagi i koordynacji, które są przyczyna upadków. Występują również zaburzenia mowy z powodu dysfunkcji języka, podniebienia, gardła czy też krtani, tak zwana dyzartia. Mowa chorego staje się cicha, powolna i niewyraźna. Pacjent ma trudności w połykaniu, występuje dysfagia. Obserwuje się także zaburzenia ruchów gałek ocznych[6,8].

Kolejnymi charakterystycznymi objawami choroby Huntingtona są objawy psychiatryczne, na które należy zwrócić szczególną 
uwagę. Zaliczamy do nich zaburzenia osobowości i zachowania. Chorzy dotknięci HD wykazują labilność emocjonalną, są drażliwi, apatyczni, mają zachowania agresywne, a nawet autoagresywne, występują zaburzenia depresyjne. Bardzo często chorzy mają myśli oraz tendencje samobójcze. Pojawiają się zaburzenia lękowe, psychozy paranoidalne, zaburzenia urojeniowo-omamowe, a także obsesyjnokompulsywne. Charakterystyczne są zaburzenia funkcji poznawczych, zwłaszcza zaburzenia dotyczące kategoryzowania i selekcjonowania informacji, planowania, ustalania celu działania i jego inicjowania. Wśród objawów psychiatrycznych obserwuje się również zaburzenia pamięci operacyjnej uwagi oraz trudności w zapamiętywaniu nowych informacji oraz zmiana nastawienia strategii działania[6,9].

\section{Rozwiązywanie problemów związanych z objawami choroby Huntingtona}

W przypadku problemów z chodzeniem oraz wystąpienia ruchów pląsawiczych pomocna jest rehabilitacja ruchowa, wykonywanie regularnych ćwiczeń, które mają na celu poprawę chodu oraz poprawę i utrzymanie sprawności fizycznej. Ważne jest, aby chory unikał sytuacji, które mogłyby wywoływać i nasilać ruchy pląsawicze. Warto wiedzieć, że stres jest jednym z takich czynników.

Otępienie jest objawem, którego nie można się uniknąć. Natomiast należy powiedzieć lekarzowi o występujących symptomach wtedy, gdy tylko ktoś z bliskich zauważy splatanie czy problemy z pamięcią. Proces otępienia może spowolnić aktywizacja mózgu poprzez regularne dokształcanie się, ciągłą edukację, rozwiązywanie krzyżówek, czytanie książek.

Depresja jest zaburzeniem psychicznym towarzyszącym chorobie Huntingtona, dlatego ważne jest by chory rozmawiał o swoich obawach i problemach z rodziną i przyjaciółmi. Nie powinien rezygnować z czynności, które sprawiały mu przyjemność, a życie towarzyskie powinien prowadzić jak dotychczas. Warto starać się, aby przynajmniej raz w tygodniu spotykać się w gronie bliskich osób. 
W przypadku, kiedy powyższe czynności nie przyniosą oczekiwanych efektów, należy zgłosić się do lekarza prowadzącego oraz do psychologa, aby rozważyć możliwości leczenia farmakologicznego.

W sytuacji, gdy pojawiają się problemy z mówieniem, zaleca się wizytę u logopedy oraz regularne wykonywanie ćwiczeń logopedycznych. Należy ustalić kod komunikacyjny, który nie będzie choremu sprawiał trudności a będzie zapobiegał izolacji społecznej. Warto również porozmawiać z osobami kontaktującymi się z pacjentem, aby poznały ten kod oraz aby nie okazywały zniecierpliwienia w czasie rozmowy z chorym, w celu uniknięcia sytuacji stresowych, które mogą wywołać wzmożenie innych objawów na przykład ruchów pląsawiczych.

Problem, którego nie można pominąć to trudności w połykaniu. Chory powinien spożywać posiłki w pozycji siedzącej, a na pewno unikać pozycji leżącej. Muszą być one spożywane często, lecz w małych ilościach, natomiast płyny winny być przyjmowane małymi łykami. Konsystencję posiłków należy dostosować do potrzeb chorego.

Kolejnym ważnym problemem są zaparcia, które są związane $\mathrm{z}$ ograniczonym poruszaniem się. $\mathrm{W}$ takiej sytuacji przydatna jest dieta bogata w błonnik, produkty kiszone i zawierające florę bakteryjną oraz masaże okolic brzucha. W przypadku, kiedy zaparcia bywają długotrwałe i przewlekłe, należy zastosować środki farmakologiczne.

Chory może mieć problemy z nocnym snem, co jest spowodowane drzemkami w ciągu dnia. Możemy pomóc pacjentowi przez zapewnienie dobrych warunków do wypoczynku oraz poprzez organizację i urozmaicenia dnia. W sytuacji, kiedy takie rozwiązania nie pomogą, należy problem zgłosić lekarzowi prowadzącemu.

Chorzy odczuwają poczucie braku bezpieczeństwa z powodu ograniczenia sprawności fizycznej. Dlatego należy zadbać o zabezpieczenia na przykład barierki przy łóżku, uchwyty w łazience i toalecie, w miejscach, gdzie chory najczęściej przebywa. 


\section{Wsparcie dla chorych i ich opiekunów}

W rozwiązywaniu wielu problemów, które codziennie się pojawiają, istotną rolę odgrywa wsparcie, które ma różnorodny zakres.

Ważne jest wsparcie emocjonalne, które ma na celu przekazywanie pozytywnych emocji, a tym samym poprawę samopoczucia chorego.

Wsparcie informacyjne polega na przekazywaniu podstawowych informacji dotyczących HD, rehabilitacji, jak również uczy jak żyć z chorobą i jak ją akceptować. Wsparciem służą także grupy samopomocowe, gdzie można dzielić się własnymi doświadczeniami związanymi z opieką nad chorym. W Polsce źródłem takiego wsparcia jest Stowarzyszenie Na Rzecz Osób z Chorobą Huntingtona.

Natomiast wsparcie instrumentalne może dostarczyć pielęgniarka, która uczy rodzinę, w jaki sposób wykonywać zabiegi pielęgnacyjne oraz jak zapobiegać powikłaniom występującym na skutek procesu chorobowego[10,11].

\section{Problemy związane z opieką nad chorym z chorobą Huntingtona}

Choroba Huntingtona jest chorobą przewlekłą, jej objawy są zróżnicowane i pojawiają się w różnych fazach choroby. Chorzy wymagają opieki sprawowanej przez opiekunów przez wiele lat, czy nawet dekad. Zarówno w Polsce, jak i innych krajach na świecie pacjenci i ich opiekunowie borykają się z podobnymi problemami. Badania Skirtona i wsp. dowodzą, że w Stanach Zjednoczonych i Wielkiej Brytanii opiekunowie chorych z HD bardzo często mają negatywne doświadczenia z opieką medyczną i społeczną. Największy problemem stanowi niedostateczny dostęp do ochrony zdrowia, a także brak wiedzy personelu medycznego na temat choroby Huntingtona. Opiekunowie mają problem ze znalezieniem instytucji z wykwalifikowanym personelem oraz placówek, które zgodziłyby się przyjąć chorego. Badanie wskazało, że lekarze nie świadczą należytej opieki i bagatelizują ich problemy [12]. Zauważalny jest także problem $\mathrm{w}$ dostępie do podstawowej i domowej opieki orazbraku miejsc w domach 
opieki społecznej, między innymi z powodu młodego wieku chorych. Pacjentom odmawia się leczenia oraz rehabilitacji. Nie mogą korzystać z preferencyjnych cen leków oraz mają ograniczony dostęp do najnowocześniejszych terapii, z tego względu, że HD jest wprawdzie chorobą rzadką, lecz nie jest na liście chorób przewlekłych. Wiele badań wskazuje na to, że opieka nad pacjentem z HD powinna być zindywidualizowana, a podstawowa wiedza na ten temat jest niewystarczająca. Warto więc rozszerzyć edukację w tym zakresie zarówno wśród personelu medycznego, jak i społeczeństwa.

Opieka nad chorym z HD jest stresująca ze względu na neuropsychiatryczny charakter choroby. Pierwsze objawy są niezauważalne, lecz z powodu zmian charakterologicznych chorego mogą zaburzyć się relacje z członkami rodziny. Brak porozumienia wynika ze sztywności myślenia chorego oraz nieporadności życiowej. Rodziny zaczynają źle funkcjonować, dochodzi do częstych kłótni, a pogłębiające się nieporozumienia małżonków prowadzą do problemów wychowawczych dzieci. Na tym etapie rozwoju choroby nikt z członków rodziny nie zauważa choroby, gdyż borykają się oni z rodzinnymi problemami, często też dochodzi do rozpadu związku, czy nawet utraty pracy. Kiedy chory zostaje zdiagnozowany jest już za późno na odwrócenie negatywnych skutków funkcjonowania rodziny wywołanych chorobą. Wielu bliskich nie jest też przygotowanych do roli opiekuna. Czasem wbrew swojej woli, czy to małżonkowie, czy też dzieci, muszą zamienić swoje role życiowe i stać się opiekunem, co jest trudne ze względu na utratę bliskości i zaburzone relacje $\mathrm{z}$ chorym.

Rozwój choroby sprawia, że pacjent stopniowo wycofuje się z życia społecznego, urywa kontakty ze znajomymi, zamyka się w domu, który traktuje jak azyl, oazę spokoju i bezpieczeństwa. Dlatego w opiece należy pamiętać o rytualnym cyklu dnia zarówno chorego jak i jego rodziny, ze względu na poczucie bezpieczeństwa pacjenta oraz dowartościowanie jego możliwości. Plan dnia i czynności powoduje ograniczenie lęku chorego, który może być wywołany po- 
przez wydarzenia, których nie zapamiętał. Nieprzewidywalne, nagłe oraz nowe sytuacje wywołują u niego lęk i niepokój. Z kolei przystosowanie się do nowych obowiązków i harmonogramu dnia jest dla opiekunów stresujące i problematyczne. Poświęcają oni choremu 24 godziny na dobę i są zmuszeni przeorganizować własne życie, zrezygnować z zainteresowań i nierzadko muszą pogodzić opiekę nad chorym z pracą zawodową. Młodzi opiekunowie czują się bezradni, mają problem z prowadzeniem normalnego życia, zmuszeni są do przejęcia wielu obowiązków, do których nie są przygotowani. Bliscy, którzy się opiekują chorym odczuwają brak czasu, zmęczenie i wyczerpanie przez co doświadczają poczucia osamotnienia, złości, frustracji, winy, co znów prowadzi do depresji. Wielu opiekunów odczuwa stres związany ze świadomością rozwoju choroby u pozostałych członków rodziny. Stąd też poczucie winy za przekazanie potomstwu choroby. Dodatkowym obciążeniem jest przedstawienie innym informacji o możliwości zachorowania. Poza tym może zdarzyć się, że podczas sprawowania opieki nad jednym chorym, zachoruje druga lub nawet trzecia osoba z rodziny. Świadomość opieki, która może trwać przez wiele lat nad kilkoma osobami równocześnie wzbudza lęk i strach $[6,8,10,13]$.

\section{Podsumowanie}

Pacjenci w przebiegu choroby Huntigtona wymagają opieki zdrowotnej i socjalnej, do której wraz z opiekunami mają utrudniony dostęp. Istnieje zatem konieczność dokonania zmian systemowych i polepszenia dostępu do opieki medycznej i socjalnej oraz tworzenia i współpracy zespołów terapeutycznych. Do prawidłowego funkcjonowania zespołów terapeutycznych potrzebna jest też wiedza i wymiana doświadczeń. Konieczna jest zatem edukacja na temat choroby Huntingtona zarówno personelu medycznego, jak i pracowników socjalnych oraz rodzin i bliskich chorego. 


\section{Zalecenia dla praktyki pielęgniarskiej}

Analiza problemów pacjentów z HD i ich opiekunów wskazuje na potrzebę prowadzenia poradnictwa oraz działań pomocowych w zakresie radzenia sobie ze stresem oraz rozwiązywania problemów związanych z opieką od momentu diagnozy przez cały czas trwania choroby.

\section{Bibliografia/Bibliography:}

1. Brandon S. L., Phyllis C. Z. Zaburzenia okołodobowe rytmów snu i czuwania. Medycyna Praktyczna. 2007;10: 80-85.

2. http://wylecz.to/pl/choroby/neurologia-i-psychiatria/chorobahuntingtona.html.

3. Warchala A. Organiczne zaburzenia psychiczne. Choroba Huntingtona. Psychiatria Podręcznik dla studentów pielęgniarstwa. ŚUM, Katowice 2007: 79.

4. http://www.mz.gov.pl/ .

5. http://www.huntington.pl/.

6. Sołtan W., Gołębiewska E., Limon J. Choroba Huntingtona - trzy punkty widzenia. Forum Medycyny Rodzinnej. 2011; 5(2): 108-114.

7. Ross, C. A. Huntington's disease: new paths to pathogenesis. Cell. 2004; 118, 4-7.

8. Domaradzki J. Wpływ choroby Huntingtona na opiekunów rodzinnych - przegląd literatury. Psychiatr. Pol. 2015; 49(5): 931-944.

9. Gołębiewska E., Sitek E. Huntington: wynik nieprawidłowy. Charaktery. $2010 ; 165$ : 78-82. 
10. Kawczyńska - Butrym.: Rodzina - zdrowie -choroba. Koncepcje i praktyka pielęgniarstwa rodzinnego. Wydawnictwo Czelej, Lublin 2001.

11. Owecki M., Kozubski W.: Podłoże molekularne a obraz kliniczny pląsawicy Huntingtona. Nowiny Lekarskie. 200;,70,6:640-646

12. Skirton $H$, Williams JK, Jackson BJ, Paulsen JS. Family carer personal concerns in Huntington disease. J. Adv. Nurs. 2012; 68(1): 137-146.

13. Pickett T, Altmaier E, Paulsen JS. Caregiver burden in Huntington's disease. Rehabil. Psychol. 2007; 52(3): 311-318. 